\title{
Assessment of Chronological Records of Rare Earth Elements in Sidi Moussa Lagoon Sediment (North-Western Morocco)
}

\author{
Ayoub Benmhammed ${ }^{1, *}$, Abdelmourhit Laissaoui ${ }^{2}$, Nezha Mejjad ${ }^{3}$, El Mahjoub Chakir ${ }^{1}$, \\ Nadia Ziad $^{4}$, Azzouz Benkdad ${ }^{2}$, Adil El Yahyaoui ${ }^{2}$, Hasna Ait Bouh ${ }^{2}$ \\ ${ }^{1}$ Laboratory of Materials Physics and Subatomic, Faculty of Sciences, Ibn Tofail University, Kenitra, Morocco \\ ${ }^{2}$ National Center for Energy Sciences and Nuclear Techniques (CNESTEN), BP1382, 1001 Rabat, Morocco \\ ${ }^{3}$ Laboratory of Applied Geology, Geomatics and Environment, Faculty of Sciences Ben M'Sik, B.P 7955, 20670, Casablanca, Morocco \\ ${ }^{4}$ National School of Applied Sciences, Ibn Tofail University, Kenitra, Morocco
}

Received June 10, 2021; Revised July 26, 2021; Accepted August 22, 2021

\section{Cite This Paper in the following Citation Styles}

(a): [1] Ayoub Benmhammed, Abdelmourhit Laissaoui, Nezha Mejjad, El Mahjoub Chakir, Nadia Ziad, Azzouz Benkdad, Adil El Yahyaoui, Hasna Ait Bouh, "Assessment of Chronological Records of Rare Earth Elements in Sidi Moussa Lagoon Sediment (North-Western Morocco)," Environment and Ecology Research, Vol. 9, No. 4, pp. 186 - 195, 2021. DOI: 10.13189/eer.2021.090406.

(b): Ayoub Benmhammed, Abdelmourhit Laissaoui, Nezha Mejjad, El Mahjoub Chakir, Nadia Ziad, Azzouz Benkdad, Adil El Yahyaoui, Hasna Ait Bouh (2021). Assessment of Chronological Records of Rare Earth Elements in Sidi Moussa Lagoon Sediment (North-Western Morocco). Environment and Ecology Research, 9(4), 186 - 195. DOI: 10.13189/eer.2021.090406.

Copyright $\bigcirc 2021$ by authors, all rights reserved. Authors agree that this article remains permanently open access under the terms of the Creative Commons Attribution License 4.0 International License

\begin{abstract}
Rare Earth Elements and yttrium (REEs+Y) were measured by inductively Coupled Plasmas - Mass Spectrometry in two previously dated sediment cores collected from Sidi Moussa lagoon, located in the Moroccan Atlantic coast, in order to establish the historical inputs of these elements and to determine the contribution of anthropogenic activities. In an attempt to clarify the phase associations of $\mathrm{REE}+\mathrm{Y}$, the $\mathrm{Ce}$ anomaly profiles were partitioned into three parts: the upper part with negative anomalies, except for a positive $\mathrm{Ce} / \mathrm{Ce}^{*}$ peak in 1983, the middle part with positive anomalies rising to high $\mathrm{Ce} / \mathrm{Ce}^{*}$, and the lower part with also fairly increasing positive anomalies. Pearson correlations were calculated between $\mathrm{REE}+\mathrm{Y}$ and major elements $(\mathrm{Mn}, \mathrm{Fe}$ and $\mathrm{Al})$ in different parts of Core-1. REE+Ys, except for Pr, were significantly correlated only with $\mathrm{Mn}$, which suggests that the associated phase in the upper part consists of Mn oxides. The central part is characterized by a negative correlation of REE+Y with Mn and a positive correlation with Fe. The maximal concentrations were observed in two horizons in the sediment cores being attributed to both natural and industrial sources. The association of REEs with manganese oxides, iron-rich minerals and detritus material
\end{abstract}

was changing in different parts of the cores. Only in specific layers, all REEs were weakly to moderately enriched, while yttrium was moderately to strongly enriched. The notable reduction in the upper layers is a reflection of the environmental management plan implemented by the phosphate company and the change in the morphology of the lagoon, which has reduced communication with the ocean.

Keywords Sidi Moussa Lagoon, Rare Earth Elements and Y, Phase Association, Cerium Europium Anomalies

\section{Introduction}

The Sidi Moussa lagoon is a coastal ecosystem separated from the Atlantic Ocean by a cord of consolidated dunes which ensures the stability of the lagoon-ocean communication. It is extended over $5.5 \mathrm{~km}$ length parallel to the coastline, with an average width of $0.5 \mathrm{~km}$. The total area including the flood zones is about $4.2 \mathrm{~km}^{2}$. The lagoon is divided into three sectors: a pass 
ensuring permanent communication with the ocean, a relatively thick sandpit in downstream part of the lagoon and a main channel that branches out into several smaller channels. The spatial distribution of the sedimentary facies is mainly influenced by tidal currents which are strong in the downstream part and weaken upstream of the lagoon which enables fine particles deposition [1]. The lagoon is part of the Oualidia - Sidi Moussa complex, ranked by the Ramsar Convention (site $\mathrm{N}^{\circ}$ 1474) as a wetland of biological and ecological importance and an area for migratory bird protection. The whole area is under substantial environmental stresses, mainly caused by anthropogenic activities such as agriculture, breeding, oyster farming, saltworks, fishing, tourism and increasing phosphate industry $[2,3,4,5]$.

Rare Earth Elements and yttrium (REEs+Y) are metals having chemical properties quite similar and therefore exhibit the same geochemical behavior [6]. They exist generally in the +3 oxidation state, but Europium (Eu) and Cerium (Ce) can display altered behavior from their neighboring elements (anomalies), usually due to changes in redox conditions during short time scales $[7,8]$. REEs are widely present in environmental matrices, generally in trace amounts. However, anthropogenic activities caused a substantial enhancement of REEs concentration in the environment, especially in coastal ecosystems.

The objective of this work was to assess REEs+Y inputs to Sidi Moussa lagoon during the last century using two previously dated sediment cores, and to highlight the contribution of anthropogenic activities as a source of REEs concentrations in sediment. The geochemistry of recent sediment of Sidi Moussa lagoon has been investigated $[1,9,10,11]$, but no data on REEs in this zone has been reported in the scientific literature. Previous studies were focused on the assessment of trace metals pollution in sediment and living organisms, usually used as bio-indicators of water quality.

\section{Material and Methods}

Two sediment cores were collected from Sidi Moussa lagoon at low tide near the landward bank of the main channel of Sidi Moussa lagoon (Core-1: 32 $59^{\prime} 42.2^{\prime \prime} \mathrm{N}$; $8^{\circ} 44^{\prime} 3.1$ ' W, $34 \mathrm{~cm}$ and Core-2: 32॰59'16" N; 8०44'9" W, $44 \mathrm{~cm}$ ). Figure 1 shows a map of the lagoon and the sampling locations. The equipment used was Uwitec corer fitted with PVC tubes with a 10-cm internal diameter. In order to avoid particle redistribution, the cores were sectioned at $2-\mathrm{cm}$ intervals immediately after retrieval and then they are transported to the laboratory for sample preparation and subsequent analyses. Each sub-sample was dried in an oven at $80^{\circ} \mathrm{C}$ for $24 \mathrm{~h}$, gently ground with a mortar and pestle and homogenised.

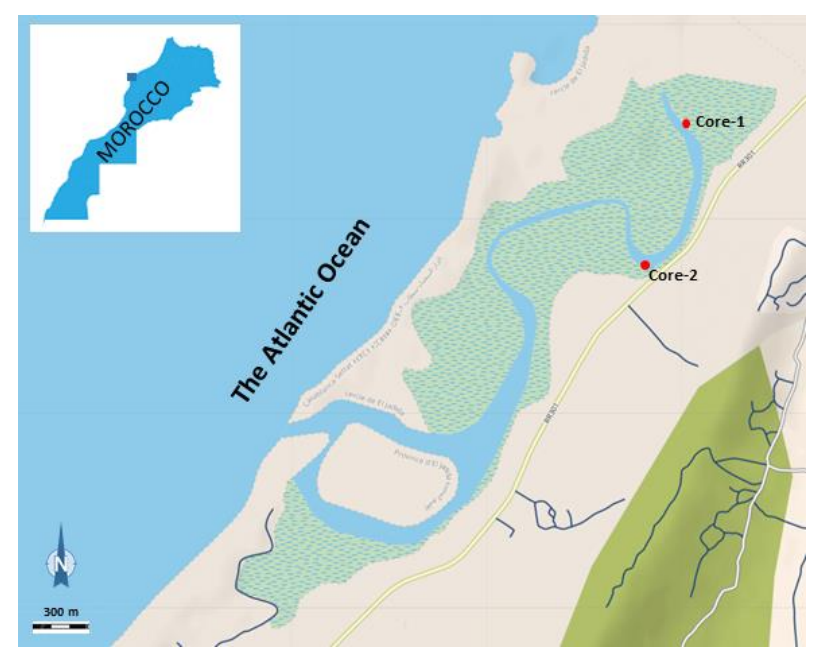

Figure 1. Map of Sidi Moussa lagoon showing the sampling location in the upstream part

Rare Earth Elements, yttrium, and major elements (Fe, $\mathrm{Mn}$, and $\mathrm{Al}$ ) were determined in samples by Inductively Coupled Plasma - Mass Spectrometry (ICP-MS). This ultimate was carried out using a Thermo Scientific XSERIES 2 (Thermo Fisher Scientific, Bremen, Germany). The spectrometer is optimized to provide minimal values of the ratios $\mathrm{CeO}^{+} / \mathrm{Ce}^{+}$and $\mathrm{Ba}^{2+} / \mathrm{Ba}^{+}$and optimum intensity of the analytes. External calibration was performed using monoelement solutions SPEX CertiPrep and for lanthanoids Astasol-mix (AN 9088 $(\mathrm{MN}))$. The correlation coefficient for all calibration curves was 0.99 . For quality control, a standard reference material, SRM 694 'Western Rock Phosphate' (National Institute of Standard and Technologies, Gaithersburg, MD, USA) was used to check the accuracy of the method. Rh $0.01 \mathrm{mg} / \mathrm{L}$ and $\operatorname{Ir} 0.01 \mathrm{mg} / \mathrm{L}$ were used as internal standards.

The analytical procedure consisted of digesting $50 \mathrm{mg}$ of sediment sample with a mixture of concentrated ultra-pure grade acids $\left(3 \mathrm{ml} \mathrm{HNO}_{3}\right.$ ultrapure $60 \%+5 \mathrm{ml}$ $\mathrm{HF} 40 \%$ ) at high pressure and temperature by microwave SPEEDWAVE4 (BERGHOF). After cooling, the liquid was transferred quantitatively in a $50 \mathrm{ml}$ Teflon flask and evaporated to dryness in the presence of $\mathrm{H}_{3} \mathrm{BO}_{3}$ to remove the excess HF. Finally, the solution was brought to the required volume with ultrapure water being ready to be measured by ICP-MS. The Quality control consisted in analyzing the reference material IAEA-433, a marine sediment, in the same conditions as the samples. Recoveries were ranging between 98 and $107 \%$ for eight elements ( $\mathrm{La}, \mathrm{Ce}, \mathrm{Nd}, \mathrm{Sm}, \mathrm{Eu}, \mathrm{Tb}, \mathrm{Yb}$ and Lu). Although recoveries were calculated using the reference material concentrations, given only as information values, the measured results were all within their respective $95 \%$ confidence intervals. 


\section{Results and Discussion}

\subsection{Vertical Distribution of Rare Earth Elements + Yttrium}

The two cores were previously dated by using lead- 210 and cesium-137 as chronometer and time-marker respectively, to obtain the age-depth relationships. The Constant Rate of Supply (CRS) dating model was applied for this purpose and the results were published in a separate paper [12]. The vertical profiles of REEs+Y versus CRS ages are plotted in Figure 2, in which the historical input of these trace elements to Sidi Moussa lagoon can be appreciated. The profile shapes in both cores were all similar, making the same geochemical behavior and a common origin evident. Relatively low concentrations were recorded down cores, which could be considered as local background levels, although some Light REEs (LREEs) were lower than the mean Upper Continental Crust (UCC) and North American Shale Composite (NASC) values [13,14]. The other elements, mostly Heavy REE (HREEs) and Y, are exceeded by almost twofold the geochemical reference values. Above these background levels, concentrations peaked during the period between 1888 and 1905, decrease before peaking again during the decade between 1983 and 1993, and then concentrations decline gradually to reach almost the background levels. The values found in downcore layers are comparable to REEs concentrations measured in Bouregrag river sediment located at some $300 \mathrm{~km}$ north the study site [15], while in top layers, Y and HREE contents were much higher than those of Bouregrag river and $\mathrm{Ce}, \mathrm{Pr}, \mathrm{Nd}$ were lower.

The first peak registered in downcore layers could be considered, in the absence of any significant anthropogenic activity in the area during that period, due to a natural event that caused the incorporation of a large number of REEs to the lagoon sediment. In contrast, the subsurface peak could have as origin the phosphogypsum discharged from the biggest phosphate processing plants, located at about $15 \mathrm{~km}$ north the study site, commissioned since 1986. The smooth decrease in the top layers is likely due to i) the effect of the environmental management plan implemented by the Moroccan phosphate company since early 2000s, and ii) the morphology of the downstream part of the lagoon experienced a development since 1990s, which caused a gradual decrease in the communication of the lagoon with the ocean [16].

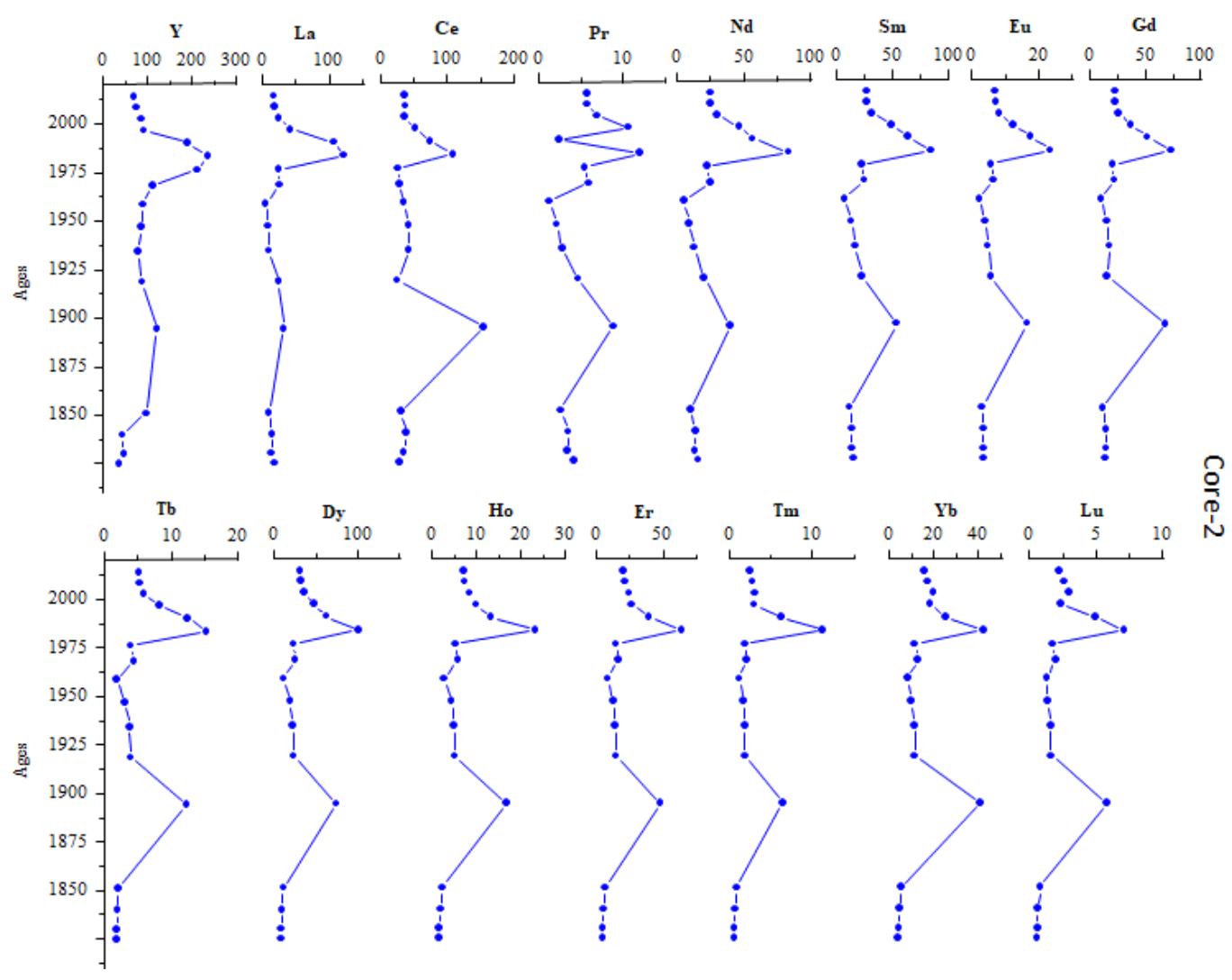




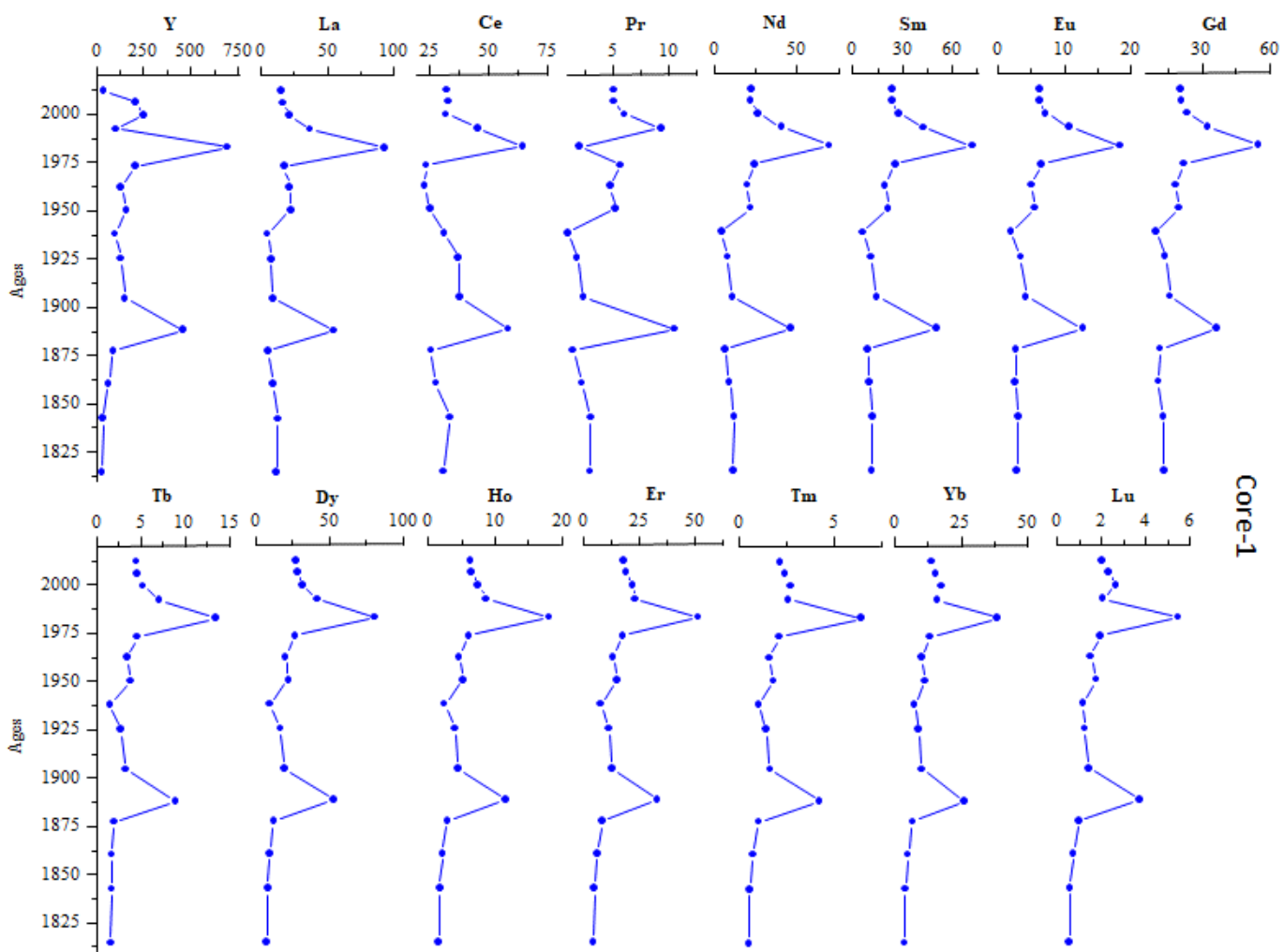

Figure 2. Concentration of REEs $+\mathrm{Y}(\mathrm{mg} / \mathrm{kg})$ vs ages in the two sediment cores collected from Sidi Moussa lagoon

Table 1. Total concentrations of REE, LREE and HREE throughout both cores along with those of UCC [13], NASC [14] and the Moroccan phosphogypsum [20]

\begin{tabular}{|c|c|c|c|c|c|c|c|}
\hline \multicolumn{4}{|c|}{ Core-1 } & \multicolumn{4}{|c|}{ Core-2 } \\
\hline CRS Ages & $\Sigma \mathrm{RRE}$ & $\Sigma$ LRRE & $\Sigma$ HRRE & CRS Ages & $\Sigma \mathrm{RRE}$ & $\Sigma$ LRRE & $\Sigma$ HRRE \\
\hline 2012 & 199 & 99 & 101 & 2014 & 225 & 112 & 114 \\
\hline 2006 & 206 & 100 & 106 & 2009 & 233 & 113 & 119 \\
\hline 2000 & 234 & 114 & 120 & 2003 & 265 & 129 & 136 \\
\hline 1992 & 319 & 174 & 144 & 1997 & 367 & 201 & 166 \\
\hline 1983 & 589 & 301 & 288 & 1990 & 536 & 303 & 233 \\
\hline 1973 & 198 & 97 & 101 & 1984 & 772 & 411 & 361 \\
\hline 1962 & 167 & 89 & 78 & 1976 & 189 & 100 & 89 \\
\hline 1950 & 183 & 96 & 87 & 1968 & 207 & 109 & 98 \\
\hline 1938 & 90 & 47 & 42 & 1959 & 101 & 54 & 48 \\
\hline 1925 & 130 & 66 & 64 & 1947 & 147 & 75 & 72 \\
\hline 1905 & 148 & 75 & 74 & 1934 & 168 & 85 & 83 \\
\hline 1888 & 411 & 221 & 190 & 1919 & 181 & 97 & 84 \\
\hline 1877 & 96 & 48 & 48 & 1894 & 578 & 289 & 289 \\
\hline 1861 & 97 & 58 & 39 & 1851 & 111 & 66 & 44 \\
\hline \multirow[t]{3}{*}{1843} & 111 & 73 & 38 & & 126 & 84 & 43 \\
\hline & 104 & 69 & 36 & & 119 & 78 & 41 \\
\hline & 107 & 71 & 36 & & 121 & 81 & 41 \\
\hline UCC & 148 & 133 & 15 & & 148 & 133 & 15 \\
\hline NASC & 165 & 144 & 22 & & 165 & 144 & 22 \\
\hline Phosphog. & 278 & 219 & 59 & & 278 & 219 & 59 \\
\hline
\end{tabular}


Total concentrations of REEs ( $\Sigma$ REE), light REEs ( LREE) and heavy REEs ( $\mathrm{HHREE)} \mathrm{were} \mathrm{calculated} \mathrm{in}$ each layer of both cores, as listed in Table 1. Along with those in UCC, NASC. REE values were lesser than those in UCC and NASC in downcore layers deposited up to 1950 , except at the layer where concentrations peaked. After 1950, $\Sigma$ REE were higher than the geochemical references, in particular, during the period $1983-1992$. On the other hand, a weak enrichment of LREE over HREE was recorded throughout the cores, being significantly weak to what is reported for the geochemical references. Indeed, $\Sigma$ LREE/ $/$ HREE ratios ranged from 0.95 to 2 with the highest values recorded in downcore layers. These values were still much lower than those corresponding to UCC (8.6), NASC (6.6) and to the Moroccan phosphogypsum, but they were similar to ratios found in deep-sea sediments in the North Atlantic Ocean [17]. It is well established that deep seawater displays significant enrichment of HREE due to the preferential scavenging of LREE by particles, and stronger complexation of HREE. Consequently, HREEs are abundant in deep sediment due to excessive toxic conditions and high adsorption capacity of particles [18]. Therefore, in view of the similarity between the $\Sigma$ LREE/ $/$ HREE ratios in our sediment and those of deep environments, a possible origin of REEs present in Sidi
Moussa lagoon could be the upwelling activity in North-West Africa [19]. Another contribution to a lesser extent, which is visible only in subsurface layers in the cores, the phosphogypsum effluents discharged into the Atlantic Ocean by the phosphate industrial plants, commissioned in 1986, and agricultural activities in the study area.

\subsection{Correlations and $\mathrm{Ce}$ and Eu Anomalies}

Pearson's correlation coefficients among REEs+Y and $\mathrm{Mn}, \mathrm{Fe}$ and $\mathrm{Al}$ were determined in both sections of cores, as is shown in Table 3. All REEs and Y, except praseodymium $(\mathrm{Pr})$, were highly and positively correlated with one another (correlations range from 0.83 to 1 at $\mathrm{p}<$ $0.05, \mathrm{~N}=17$ ). Nevertheless, no significant correlations between REEs+Y and major elements ( $\mathrm{Mn}, \mathrm{Fe}$ and $\mathrm{Al}$ ) were observed in Core-1, while among major elements, only $\mathrm{Al}$ is correlated with $\mathrm{Mn}$. Such lack of correlations excludes any significant association of REEs+Y with $\mathrm{Mn}$ oxides, Fe oxhydroxydes or clay minerals and detrital inputs in the overall Core-1. In contrast, $\mathrm{Mn}$ and $\mathrm{Fe}$ are quite significantly correlated with almost all REEs in Core-2, suggesting their association with both manganese oxides and iron-rich minerals, but not with detritus material, since correlations with $\mathrm{Al}$ were weak.

Table 2. Pearson's correlations among Rare Earth and Major Elements $(\mathrm{p}<0.05, \mathrm{~N}=17)$. The lower part of the table corresponds to Core- 1 and the upper part (grey shaded background) to Core-2.

\begin{tabular}{|c|c|c|c|c|c|c|c|c|c|c|c|c|c|c|c|c|c|c|}
\hline & $\mathbf{Y}$ & La & $\mathrm{Ce}$ & Pr & Nd & Sm & Eu & Gd & Tb & Dy & Ho & $\mathbf{E r}$ & $\mathbf{T m}$ & $\mathbf{Y b}$ & Lu & Mn & $\mathbf{F e}$ & Al \\
\hline $\mathbf{Y}$ & 1,00 & 0,77 & 0,45 & 0,39 & 0,71 & 0,70 & 0,71 & 0,66 & 0,70 & 0,70 & 0,70 & 0,71 & 0,74 & 0,64 & 0,71 & 0,71 & 0,66 & 0,35 \\
\hline La & 0,90 & 1,00 & 0,56 & 0,50 & 0,94 & 0,92 & 0,90 & 0,81 & 0,87 & 0,84 & 0,83 & 0,83 & 0,88 & 0,73 & 0,82 & 0,78 & 0,73 & 0,34 \\
\hline $\mathrm{Ce}$ & 0,79 & 0,84 & 1,00 & 0,54 & 0,66 & 0,75 & 0,80 & 0,91 & 0,83 & 0,83 & 0,83 & 0,84 & 0,80 & 0,88 & 0,85 & 0,37 & 0,34 & 0,07 \\
\hline Pr & 0,23 & 0,35 & 0,29 & 1,00 & 0,76 & 0,74 & 0,71 & 0,71 & 0,69 & 0,75 & 0,75 & 0,73 & 0,67 & 0,73 & 0,66 & 0,62 & 0,73 & 0,41 \\
\hline Nd & 0,86 & 0,97 & 0,80 & 0,51 & 1,00 & 0,99 & 0,97 & 0,91 & 0,94 & 0,94 & 0,93 & 0,93 & 0,93 & 0,85 & 0,89 & 0,82 & 0,82 & 0,40 \\
\hline Sm & 0,88 & 0,97 & 0,83 & 0,50 & 1,00 & 1,00 & 1,00 & 0,96 & 0,98 & 0,97 & 0,96 & 0,96 & 0,95 & 0,91 & 0,94 & 0,77 & 0,74 & 0,35 \\
\hline Eu & 0,89 & 0,96 & 0,84 & 0,49 & 0,99 & 1,00 & 1,00 & 0,98 & 0,99 & 0,99 & 0,98 & 0,98 & 0,97 & 0,94 & 0,96 & 0,75 & 0,72 & 0,32 \\
\hline Gd & 0,89 & 0,97 & 0,83 & 0,45 & 0,99 & 1,00 & 1,00 & 1,00 & 0,98 & 0,98 & 0,97 & 0,97 & 0,95 & 0,97 & 0,97 & 0,65 & 0,63 & 0,28 \\
\hline $\mathbf{T b}$ & 0,91 & 0,96 & 0,84 & 0,44 & 0,98 & 0,99 & 1,00 & 0,99 & 1,00 & 0,99 & 0,98 & 0,98 & 0,96 & 0,96 & 0,97 & 0,72 & 0,68 & 0,30 \\
\hline Dy & 0,91 & 0,94 & 0,84 & 0,43 & 0,97 & 0,98 & 0,99 & 0,99 & 1,00 & 1,00 & 1,00 & 1,00 & 0,98 & 0,97 & 0,98 & 0,77 & 0,74 & 0,33 \\
\hline Но & 0,92 & 0,94 & 0,83 & 0,41 & 0,96 & 0,98 & 0,98 & 0,98 & 1,00 & 1,00 & 1,00 & 1,00 & 0,98 & 0,98 & 0,98 & 0,78 & 0,76 & 0,34 \\
\hline Er & 0,93 & 0,93 & 0,82 & 0,39 & 0,96 & 0,97 & 0,98 & 0,98 & 0,99 & 1,00 & 1,00 & 1,00 & 0,98 & 0,98 & 0,99 & 0,77 & 0,74 & 0,34 \\
\hline Tm & 0,95 & 0,93 & 0,82 & 0,37 & 0,94 & 0,96 & 0,97 & 0,97 & 0,98 & 0,99 & 1,00 & 1,00 & 1,00 & 0,94 & 0,98 & 0,80 & 0,78 & 0,34 \\
\hline $\mathbf{Y b}$ & 0,95 & 0,92 & 0,82 & 0,38 & 0,94 & 0,96 & 0,96 & 0,96 & 0,98 & 0,99 & 0,99 & 1,00 & 1,00 & 1,00 & 0,98 & 0,68 & 0,66 & 0,32 \\
\hline Lu & 0,95 & 0,91 & 0,79 & 0,37 & 0,93 & 0,94 & 0,95 & 0,95 & 0,97 & 0,98 & 0,99 & 0,99 & 1,00 & 1,00 & 1,00 & 0,73 & 0,69 & 0,34 \\
\hline Mn & 0,42 & 0,48 & 0,57 & $-0,19$ & 0,38 & 0,39 & 0,41 & 0,44 & 0,42 & 0,42 & 0,41 & 0,40 & 0,40 & 0,39 & 0,36 & 1,00 & 0,97 & 0,58 \\
\hline $\mathrm{Fe}$ & $-0,26$ & $-0,07$ & $-0,17$ & 0,26 & $-0,08$ & $-0,13$ & $-0,16$ & $-0,15$ & $-0,23$ & $-0,28$ & $-0,31$ & $-0,32$ & $-0,33$ & $-0,33$ & $-0,34$ & $-0,05$ & 1,00 & 0,62 \\
\hline Al & $-0,31$ & $-0,23$ & $-0,24$ & $-0,22$ & $-0,34$ & $-0,37$ & $-0,39$ & $-0,37$ & $-0,43$ & $-0,46$ & $-0,48$ & $-0,47$ & $-0,47$ & $-0,47$ & $-0,48$ & 0,07 & 0,81 & 1,00 \\
\hline
\end{tabular}


$\mathrm{Ce}$ and $\mathrm{Eu}$ anomalies, reflecting their abundances and resulting from changes in oxidation states $\left(\mathrm{Ce}^{3+}-\mathrm{Ce}^{4+}\right.$ and $\left.\mathrm{Eu}^{2+}-\mathrm{Eu}^{3+}\right)$, are widely used to assess variations in redox conditions during sediment deposition and differences in the complexation of REEs and their adsorption behaviour $[21,22]$. Ce and $\mathrm{Eu}$ anomalies were calculated by comparing their NASC-normalized concentrations with their respective neighbouring REEs as follows:

$$
\begin{gathered}
C e / C e^{*}=\frac{\left(C e / C e_{N A S C}\right)}{\sqrt{\left(L a / L a_{N A S C}\right) \cdot\left(P r / P r_{N A S C}\right)}} \\
E u / E u^{*}=\frac{\left(E u / E u_{N A S C}\right)}{\sqrt{\left(S m / S m_{N A S C}\right) \cdot\left(G d / G d_{N A S C}\right)}}
\end{gathered}
$$

$\mathrm{Ce} / \mathrm{Ce}^{*}$ values less than 1 are indicative of depletion in sediment, produced by reduction of the insoluble $\mathrm{Ce}^{+4}$ to soluble $\mathrm{Ce}^{+3}$, and values $>1$ reflect oxidation. $\mathrm{Eu} / \mathrm{Eu}^{*}$ values $<1$ suggest loss of Eu from the sediment due to its oxidation from $\mathrm{Eu}^{+2}$ to $\mathrm{Eu}^{+3}$ and vice-versa. Depth profiles of $\mathrm{Ce}$ and $\mathrm{Eu}$ anomalies in both cores are shown in Figure 3. Cerium anomaly profiles exhibit large variations throughout the cores with values ranging from negative anomalies (0.57) to high positive anomalies (3.66), while Europium anomaly profiles displayed positive values with lesser variability $(1.1-1.37)$. Ce.A slightly increases Ce anomalies in downcore sections. A negative anomaly in the layer where the first peak of maximum $\Sigma$ REE was registered, a significant increase reaches a maximum around 1940 and then there is a sudden decline of negative anomalies in the upper layers, except for a positive anomaly registered around in the 1980s (the subsurface $\Sigma$ REE maximum). Such variability suggested different depositional environmental conditions over time, which produced intermittent $\mathrm{Ce}$ depletion/enrichment in sediment, and different sources of REEs to the lagoon. As cerium was found to be significantly correlated with the other REEs, except Pr, it should be considered that post-depositional changes in $\mathrm{Ce}$ anomalies did not take place. However, the profiles are affected by two REEs inputs of different origins and periods: 1) the downcore negative anomaly is attributable to a natural event (possibly coastal upwelling associated with hydrological regime) which produced input of RREs depleted in $\mathrm{Ce}$, characteristic of deep-sea waters [17-23], and 2) the positive anomaly recorded at the subsurface section is indicative of an anthropogenic source of REEs to the lagoon sediment, likely the phosphogypsum effluents and agricultural activities. Negative $\mathrm{Ce}$ anomalies were reported for sandy sediment from the Oualidia lagoon located at about $50 \mathrm{~km}$ from the study site [23].
Positive Europium anomaly, ranging from 1.1 to 1.4, were observed in all layers of both cores which is quite unusual, and the profiles showed similar trends. The highest values were recorded at depths where maximum concentrations of all REEs were registered in the sediment cores, suggesting substantial uptake of Eu by sediment in relatively high concentration. Marine sediment exhibit, in general, negative anomaly [21], and Eu/Eu*> 1 develop normally in hydrothermal and/or high reducing conditions [24]. In view of no evidence of such processes in the study area, positive Eu anomalies could be due to the origin of sediment which is understood to be a mixture of a continental component from weathering, and a marine component [25].

To elucidate phase associations of REEs $+\mathrm{Y}$, the Ce anomaly profiles was divided into three parts: the top with negative anomalies except a positive $\mathrm{Ce} / \mathrm{Ce}^{*}$ peak in 1983 , the middle with positive anomalies increasing to high $\mathrm{Ce} / \mathrm{Ce}^{*}$ and the bottom with also a fairly increasing positive anomalies. Pearson's correlations were calculated between REEs+Y and major elements ( $\mathrm{Mn}, \mathrm{Fe}$ and $\mathrm{Al}$ ) in different parts of Core-1. REEs+Y, except Pr, were significantly correlated only with Mn suggesting that the associated phase in the top part is Mn oxides. The middle part is characterized by negative correlation of REEs+Y with $\mathrm{Mn}$ and positive correlation with $\mathrm{Fe}$. The carrier phase in this case should be Fe-rich minerals and detrital inputs as $\mathrm{Fe}$ and $\mathrm{Al}$ were strongly correlated $\left(\mathrm{r}^{2}=0.94\right)$. However, the bottom part exhibited a peculiar pattern of correlations; major elements were correlated with one another, negatively associated with $\mathrm{Y}$, and positively correlated with LREEs, except to $\mathrm{Ce}$, and well correlated with Eu and Gd. The remaining HREEs were negatively correlated with $\mathrm{Fe}$ and $\mathrm{Al}$, but weakly to $\mathrm{Mn}$. The reason of such different behaviour among REEs is unclear. The decoupling of $\mathrm{Y}$ and $\mathrm{Ce}$ from the LREEs is suggestive of fractionation likely due to preferential scavenging of individual REEs over the others [26].
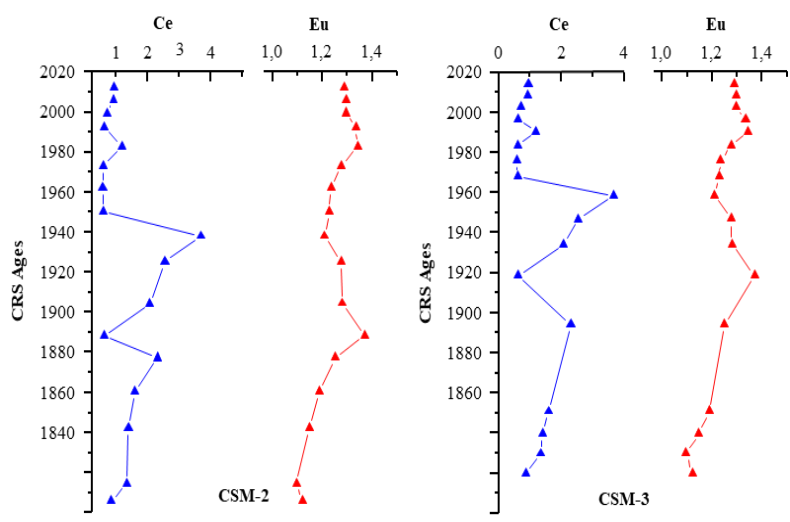

Figure 3. Temporal evolution of Cerium and Europium anomalies throughout the two cores collected from Sidi Moussa lagoon 
Table 3. Pearson's correlations between REEs $+\mathrm{Y}$ and major elements (Mn, Fe and Al) in different parts of Core-1

\begin{tabular}{|c|c|c|c|c|c|c|c|c|c|c|c|c|c|c|c|c|c|c|}
\hline \multicolumn{19}{|c|}{ Top } \\
\hline & $\mathrm{Y}$ & $\mathrm{La}$ & $\mathrm{Ce}$ & $\operatorname{Pr}$ & $\mathrm{Nd}$ & $\mathrm{Sm}$ & $\mathrm{Eu}$ & $\mathrm{Gd}$ & $\mathrm{Tb}$ & Dy & Ho & $\mathrm{Er}$ & $\mathrm{Tm}$ & $\mathrm{Yb}$ & $\mathrm{Lu}$ & $\mathrm{Mn}$ & $\mathrm{Fe}$ & $\mathrm{Al}$ \\
\hline $\mathrm{Mn}$ & 0,67 & 0,88 & 0,76 & $-0,35$ & 0,86 & 0,85 & 0,85 & 0,86 & 0,83 & 0,81 & 0,80 & 0,78 & 0,75 & 0,74 & 0,69 & 1,00 & & \\
\hline $\mathrm{Fe}$ & $-0,36$ & $-0,35$ & $-0,48$ & 0,61 & $-0,32$ & $-0,34$ & $-0,35$ & $-0,35$ & $-0,40$ & $-0,43$ & $-0,45$ & $-0,47$ & $-0,50$ & $-0,51$ & $-0,53$ & $-0,16$ & 1,00 & \\
\hline $\mathrm{Al}$ & 0,11 & $-0,08$ & $-0,39$ & $-0,12$ & $-0,18$ & $-0,20$ & $-0,21$ & $-0,18$ & $-0,20$ & $-0,21$ & $-0,19$ & $-0,17$ & $-0,15$ & $-0,15$ & $-0,11$ & $-0,14$ & 0,61 & 1,00 \\
\hline \multicolumn{19}{|c|}{ Middle } \\
\hline & $\mathrm{Y}$ & $\mathrm{La}$ & $\mathrm{Ce}$ & $\operatorname{Pr}$ & $\mathrm{Nd}$ & $\mathrm{Sm}$ & $\mathrm{Eu}$ & $\mathrm{Gd}$ & $\mathrm{Tb}$ & Dy & Ho & Er & $\mathrm{Tm}$ & $\mathrm{Yb}$ & $\mathrm{Lu}$ & $\mathrm{Mn}$ & $\mathrm{Fe}$ & $\mathrm{Al}$ \\
\hline $\mathrm{Mn}$ & $-0,88$ & $-0,89$ & $-0,82$ & $-0,88$ & $-0,88$ & $-0,87$ & $-0,86$ & $-0,85$ & $-0,85$ & $-0,85$ & $-0,85$ & $-0,86$ & $-0,87$ & $-0,89$ & $-0,90$ & 1,00 & & \\
\hline $\mathrm{Fe}$ & 0,97 & 0,96 & 0,99 & 0,97 & 0,97 & 0,98 & 0,98 & 0,99 & 0,99 & 0,99 & 0,99 & 0,98 & 0,98 & 0,97 & 0,96 & $-0,78$ & 1,00 & \\
\hline $\mathrm{Al}$ & 0,85 & 0,83 & 0,90 & 0,86 & 0,86 & 0,88 & 0,89 & 0,90 & 0,90 & 0,90 & 0,89 & 0,88 & 0,87 & 0,85 & 0,84 & $-0,69$ & 0,94 & 1,00 \\
\hline \multicolumn{19}{|c|}{ Bottom } \\
\hline & $\mathrm{Y}$ & $\mathrm{La}$ & $\mathrm{Ce}$ & $\operatorname{Pr}$ & $\mathrm{Nd}$ & $\mathrm{Sm}$ & $\mathrm{Eu}$ & $\mathrm{Gd}$ & $\mathrm{Tb}$ & Dy & Ho & $\mathrm{Er}$ & $\mathrm{Tm}$ & $\mathrm{Yb}$ & $\mathrm{Lu}$ & $\mathrm{Mn}$ & $\mathrm{Fe}$ & $\mathrm{Al}$ \\
\hline $\mathrm{Mn}$ & $-0,60$ & 0,61 & 0,13 & 0,62 & 0,62 & 0,68 & 0,84 & 0,92 & $-0,39$ & $-0,46$ & $-0,50$ & $-0,51$ & $-0,49$ & $-0,46$ & $-0,49$ & 1,00 & & \\
\hline $\mathrm{Fe}$ & $-0,89$ & 0,93 & 0,16 & 0,94 & 0,93 & 0,95 & 0,89 & 0,89 & $-0,79$ & $-0,83$ & $-0,85$ & $-0,86$ & $-0,85$ & $-0,83$ & $-0,85$ & 0,84 & 1,00 & \\
\hline $\mathrm{Al}$ & $-0,74$ & 0,71 & $-0,03$ & 0,73 & 0,72 & 0,73 & 0,64 & 0,79 & $-0,68$ & $-0,69$ & $-0,70$ & $-0,70$ & $-0,68$ & $-0,66$ & $-0,68$ & 0,83 & 0,89 & 1,00 \\
\hline
\end{tabular}


Table 4. Calculated Enrichment Factors throughout the two cores collected from Sidi Moussa lagoon

\begin{tabular}{|c|c|c|c|c|c|c|c|c|c|c|c|c|c|c|c|}
\hline \multicolumn{16}{|c|}{ Core-1 } \\
\hline & Y & $\mathrm{La}$ & $\mathrm{Ce}$ & $\operatorname{Pr}$ & $\mathrm{Nd}$ & $\mathrm{Sm}$ & $\mathrm{Eu}$ & $\mathrm{Gd}$ & $\mathrm{Tb}$ & Dy & Ho & Er & $\mathrm{Tm}$ & $\mathrm{Yb}$ & $\mathrm{Lu}$ \\
\hline 2012 & 0,36 & 0,63 & 0,51 & 0,85 & 0,94 & 0,98 & 0,96 & 0,76 & 1,15 & 1,35 & 1,47 & 1,47 & 1,40 & 1,35 & 1,35 \\
\hline 2006 & 1,81 & 0,67 & 0,50 & 0,83 & 0,91 & 0,94 & 0,94 & 0,75 & 1,14 & 1,36 & 1,49 & 1,54 & 1,51 & 1,46 & 1,51 \\
\hline 2000 & 2,07 & 0,82 & 0,46 & 0,93 & 1,03 & 1,04 & 1,01 & 0,79 & 1,23 & 1,44 & 1,61 & 1,65 & 1,61 & 1,56 & 1,62 \\
\hline 1992 & 0,83 & 1,36 & 0,63 & 1,39 & 1,53 & 1,55 & 1,49 & 1,07 & 1,62 & 1,82 & 1,82 & 1,69 & 1,47 & 1,39 & 1,22 \\
\hline 1983 & 6,19 & 3,85 & 1,00 & 0,34 & 2,90 & 2,94 & 2,83 & 2,01 & 3,41 & 3,94 & 4,24 & 4,23 & 4,08 & 3,73 & 3,63 \\
\hline 1973 & 1,63 & 0,65 & 0,33 & 0,84 & 0,91 & 0,93 & 0,90 & 0,72 & 1,04 & 1,17 & 1,27 & 1,27 & 1,22 & 1,15 & 1,15 \\
\hline 1962 & 1,08 & 0,83 & 0,33 & 0,73 & 0,77 & 0,73 & 0,72 & 0,62 & 0,81 & 0,92 & 0,99 & 1,00 & 0,95 & 0,91 & 0,93 \\
\hline 1950 & 1,29 & 0,83 & 0,35 & 0,78 & 0,82 & 0,79 & 0,76 & 0,65 & 0,88 & 0,97 & 1,08 & 1,09 & 1,04 & 0,99 & 1,04 \\
\hline 1938 & 0,91 & 0,19 & 0,49 & 0,17 & 0,19 & 0,24 & 0,30 & 0,35 & 0,39 & 0,49 & 0,57 & 0,62 & 0,69 & 0,73 & 0,77 \\
\hline 1925 & 1,12 & 0,30 & 0,56 & 0,29 & 0,33 & 0,44 & 0,51 & 0,48 & 0,67 & 0,80 & 0,88 & 0,89 & 0,90 & 0,83 & 0,80 \\
\hline 1905 & 1,28 & 0,35 & 0,56 & 0,39 & 0,44 & 0,56 & 0,62 & 0,56 & 0,79 & 0,92 & 1,00 & 1,00 & 1,00 & 0,93 & 0,91 \\
\hline 1888 & 3,55 & 1,97 & 0,78 & 1,51 & 1,68 & 1,78 & 1,70 & 1,16 & 1,96 & 2,22 & 2,34 & 2,35 & 2,32 & 2,18 & 2,13 \\
\hline 1877 & 0,79 & 0,21 & 0,38 & 0,24 & 0,27 & 0,35 & 0,41 & 0,40 & 0,50 & 0,58 & 0,63 & 0,63 & 0,65 & 0,63 & 0,62 \\
\hline 1861 & 0,55 & 0,35 & 0,41 & 0,36 & 0,37 & 0,39 & 0,39 & 0,37 & 0,43 & 0,45 & 0,47 & 0,47 & 0,47 & 0,46 & 0,46 \\
\hline \multirow[t]{3}{*}{1843} & 0,26 & 0,43 & 0,44 & 0,43 & 0,42 & 0,40 & 0,40 & 0,40 & 0,36 & 0,34 & 0,32 & 0,32 & 0,31 & 0,32 & 0,33 \\
\hline & 0,21 & 0,39 & 0,39 & 0,40 & 0,39 & 0,37 & 0,36 & 0,39 & 0,33 & 0,30 & 0,28 & 0,28 & 0,28 & 0,29 & 0,29 \\
\hline & 0,20 & 0,49 & 0,30 & 0,46 & 0,44 & 0,39 & 0,36 & 0,36 & 0,32 & 0,29 & 0,27 & 0,26 & 0,26 & 0,26 & 0,27 \\
\hline
\end{tabular}

\begin{tabular}{|c|c|c|c|c|c|c|c|c|c|c|c|c|c|c|c|}
\hline \multicolumn{16}{|c|}{ Core- 2} \\
\hline & $\mathrm{Y}$ & $\mathrm{La}$ & $\mathrm{Ce}$ & $\operatorname{Pr}$ & $\mathrm{Nd}$ & $\mathrm{Sm}$ & $\mathrm{Eu}$ & $\mathrm{Gd}$ & $\mathrm{Tb}$ & Dy & Ho & $\mathrm{Er}$ & $\mathrm{Tm}$ & $\mathrm{Yb}$ & $\mathrm{Lu}$ \\
\hline 2014 & 0,49 & 0,49 & 0,43 & 0,67 & 0,75 & 0,82 & 0,83 & 0,66 & 1,05 & 1,30 & 1,46 & 1,46 & 1,41 & 1,34 & 1,34 \\
\hline 2009 & 0,52 & 0,52 & 0,43 & 0,65 & 0,73 & 0,79 & 0,82 & 0,65 & 1,05 & 1,31 & 1,48 & 1,53 & 1,53 & 1,46 & 1,50 \\
\hline 2003 & 0,52 & 0,59 & 0,36 & 0,67 & 0,76 & 0,80 & 0,81 & 0,63 & 1,03 & 1,27 & 1,47 & 1,51 & 1,49 & 1,43 & 1,47 \\
\hline 1997 & 0,54 & 0,99 & 0,50 & 1,02 & 1,14 & 1,22 & 1,21 & 0,86 & 1,39 & 1,64 & 1,69 & 1,57 & 1,39 & 1,29 & 1,13 \\
\hline 1990 & 1,42 & 3,19 & 0,91 & 0,29 & 1,74 & 2,01 & 2,17 & 1,53 & 2,65 & 2,69 & 2,86 & 2,97 & 3,67 & 2,26 & 3,01 \\
\hline 1984 & 0,75 & 1,57 & 0,57 & 0,63 & 1,11 & 1,14 & 1,24 & 0,92 & 1,40 & 1,88 & 2,15 & 2,08 & 2,83 & 1,61 & 1,86 \\
\hline 1976 & 1,45 & 0,67 & 0,29 & 0,61 & 0,64 & 0,65 & 0,65 & 0,56 & 0,78 & 0,92 & 1,03 & 1,04 & 1,00 & 0,94 & 0,96 \\
\hline 1968 & 0,74 & 0,68 & 0,31 & 0,65 & 0,69 & 0,69 & 0,69 & 0,59 & 0,85 & 0,98 & 1,12 & 1,13 & 1,10 & 1,03 & 1,08 \\
\hline 1959 & 0,68 & 0,16 & 0,44 & 0,14 & 0,16 & 0,21 & 0,28 & 0,32 & 0,38 & 0,49 & 0,59 & 0,65 & 0,73 & 0,76 & 0,80 \\
\hline 1947 & 0,84 & 0,33 & 0,67 & 0,32 & 0,38 & 0,52 & 0,62 & 0,59 & 0,87 & 1,09 & 1,24 & 1,26 & 1,28 & 1,17 & 1,12 \\
\hline 1934 & 0,75 & 0,39 & 0,68 & 0,43 & 0,50 & 0,67 & 0,76 & 0,68 & 1,02 & 1,26 & 1,40 & 1,40 & 1,43 & 1,31 & 1,27 \\
\hline 1919 & 0,76 & 0,85 & 0,37 & 0,66 & 0,74 & 0,82 & 0,81 & 0,55 & 0,99 & 1,18 & 1,28 & 1,29 & 1,29 & 1,20 & 1,16 \\
\hline 1894 & 1,17 & 1,25 & 2,45 & 1,40 & 1,60 & 2,21 & 2,63 & 2,60 & 3,42 & 4,17 & 4,68 & 4,70 & 4,92 & 4,72 & 4,62 \\
\hline 1851 & 1,25 & 0,52 & 0,67 & 0,53 & 0,56 & 0,62 & 0,64 & 0,62 & 0,75 & 0,82 & 0,88 & 0,89 & 0,90 & 0,86 & 0,87 \\
\hline & 0,48 & 0,64 & 0,71 & 0,64 & 0,64 & 0,64 & 0,65 & 0,65 & 0,63 & 0,63 & 0,61 & 0,61 & 0,60 & 0,61 & 0,61 \\
\hline & 0,50 & 0,58 & 0,63 & 0,60 & 0,60 & 0,60 & 0,59 & 0,64 & 0,57 & 0,55 & 0,53 & 0,53 & 0,54 & 0,55 & 0,55 \\
\hline & 0,37 & 0,72 & 0,48 & 0,69 & 0,67 & 0,63 & 0,60 & 0,59 & 0,55 & 0,52 & 0,50 & 0,50 & 0,49 & 0,50 & 0,50 \\
\hline
\end{tabular}

The enrichment factor (EF) is a parameter widely used to asses qualitatively the inputs intensity of elements to the sediment. EF was computed using the relationship below:

$$
E F=\frac{\left({ }^{C_{X}} / C_{\text {Ref }}\right)_{\text {sample }}}{\left({ }^{C_{X}} / C_{\text {Ref }}\right)_{\text {background }}}
$$

Where $C_{X}$ and $C_{R e f}$ are the concentration of the element of interest and that of a reference element, used as a normalizer, respectively. Besides being conservative and insensitive to inputs from point and non-point sources, $\mathrm{Fe}$ was used as normalizer for the following reasons [27]: 1) it is strongly correlated with the background concentrations of REEs+Y recorded in downcore layers $\left(\mathrm{r}^{2}=0.93, \mathrm{P}=0.0257\right.$ and $\left.\left.\mathrm{N}=5\right), 2\right) \mathrm{Fe}$ concentration is fairly uniform throughout the cores (mean $=12.3$; standard deviation $=1.0$ ), and the corresponding ratio standard deviation/mean is the lowest among the studied REEs+Y. Depth-averaged concentrations in downcore layers, previously identified as background levels, were used in expression (2) as local reference values.

EFs computed along both cores are presented in Table 4. No enrichment of all REEs was observed in downcore layers prior to 1888 in Core-1, and weak enrichment in the layer deposited during the period 1888 - 1905 during which the downcore peaks of maximal concentrations, attributed to a natural event, were recorded. Y displayed in this layer an EF indicative of moderate enrichment. The period between 1905 and 1983 was characterized by non-enrichment trend relative to the local background, except $\mathrm{Y}$ and almost all HREEs, which displayed 
intermittent enrichment at barely noticeable levels. On the other hand, the highest enrichment factors for all elements were found in the layer corresponding to the period 1983 - 1992, but EFs were still in the range of weakto-moderate enrichment of REEs, while $\mathrm{Y}$ was moderately- to-strongly enriched. The anthropogenic input is expectedly visible in this part of the sediment core. A general decreasing trend was observed upwards, reaching non-enrichment state at the surface sediment. The same enrichment pattern was observed in Core-2, with the only difference that only few layers displayed moderate enrichment of some HREEs and yttrium enrichment was almost insignificant throughout the core.

\section{Conclusions}

The two analysed sediment cores collected from the upstream part of Sidi Moussa lagoon showed a significant REEs+Y enhancement at two horizons at depths corresponding to 1888-1904 and 1983-1992. The recent subsurface enrichment is attributable to phosphogypsum effluents and the upwelling activity, which prevail in North-West Africa, and agricultural practices in the surrounding area. The notable decrease in the top layers is a consequence of environmental management plan adopted by the phosphate company and to the changing morphology of the lagoon, which reduced the communication with the Ocean. The lack of correlation between REEs+Y and redox sensitive elements in the whole cores exclude any association with iron and manganese oxides. In contrast, different parts of the cores exhibited associations with Mn oxides, Fe-rich minerals, and detritus material. The computed enrichment factor throughout the cores showed values indicative of weak to moderate enrichment of REEs in specific layers, where maximal concentrations were observed, while $Y$ was found to be moderately- to-strongly enriched. REEs+Y concentrations in downcore layers were in the same range, or even below the geochemical reference level and, therefore, could be taken as local background concentrations.

\section{REFERENCES}

[1] Maanan M., Zourarah B., Carruesco C., Aajjane A., Naud J., "The distribution of heavy metals in the Sidi Moussa lagoon sediments (Atlantic Moroccan Coast)," Journal of African Earth Sciences, vol.39, no.3-5, pp.473-483, 2004. https://doi.org/10.1016/j.jafrearsci.2004.07.017

[2] Zourarah B., Maanan M., Carruesco C., Aajjane A., Mehdi K., Conceic Freitas M, "Fifty-year sedimentary record of heavy metal pollution in the lagoon of Oualidia (Moroccan Atlantic coast)". Estuarine, Coastal and Shelf Science, vol.72, no. 1-2, pp.359-369, 2007. https://doi.org/10.1016/

\section{j.ecss.2006.11.007}

[3] Daghor L., HssaïdaT., Chakir S., Slimani H., Mouflih M., Hamoumi N., El Madani F., Ennafah B., Fraikech M., El Bouhmadi K, "Etude des kystes de dinoflagellés des sédiments de surface du système lagunaire Atlantique Marocain Oualidia - Sidi Moussa et de la lagune méditerranéenne de Nador," Bulletin de l'Institut Scientifique, Rabat, Section Sciences de la Terre, $\mathrm{n}^{\circ} 381-18$, 2016.

[4] Mejjad N., Laissaoui A., El-Hammoumi O., Fekri A., Amsil H., El-Yahyaoui A., Benkdad A, "Geochemical, radiometric, and environmental approaches for the assessment of the intensity and chronology of metal contamination in the sediment cores from Oualidia lagoon (Morocco)," EnvironSciPollut.Res, vol.25, pp.2287222888, 2018. https://doi.org/10.1007/s11356-018-2370-y

[5] Mejjad N., Laissaoui A., Fekri A., Benmhammed A., El Hammoumi O., Cherif E., "Does human activities growth lead to biodiversity loss in the Moroccan coastal lagoons? A diagnostic comparison study," In Proceedings of ACM GEOIT4W-2020, March11-12, 2020a. https://doi.org/10.1 $145 / 3399205.3399231$

[6] Suja S., Fernandes L., Rao V.P., "Distribution and fractionation of rare earth elements and Yttrium in suspended and bottom sediments of the Kali estuary, western India," Environ Earth Sci, vol.76, pp.174, 2017. https://doi.org/10.1007/s12665-017-6497-9

[7] Brito P., Prego R., Mil-Homens M., Caçador I., Caetano M., "Sources and distribution of yttrium and rare earth, elements in surface sediments from Tagus estuary, Portugal," Science of The Total Environment, vol.621, pp.317-325, 2018. https://doi.org/10.1016/j.scitotenv.2017. 11.245

[8] Cheng J., Huang Y., Wang S., Miao L., Yan W., “Transect variations and controlling factors of redox-sensitive trace element compositions of surface sediments in the South China Sea," Continental Shelf Research, vol.190, pp.103978, 2019. https://doi.org/10.1016/j.csr.2019.10397 8

[9] Cheggour M., Chafik A., Langston W.J., Burt G.R., Benbrahim S., Texier H, "Metals in sediments and the edible cockle Cerastodermaedule from two moroccanatlanticlagoons: Moulay Bousselham and Sidi Moussa," Environmental pollution, vol.115 pp.149-160, 2001. https://doi.org/10.1016/S0269-7491(01)00117-8

[10] Kaimoussi A., Chafik A., Mouzdahir A., Bakkas S., "The impact of industrial pollution on the JorfLasfar coastal zone (Morocco atlantic ocean): the mussel as an indicator of metal contamination," C. R. Acad. Sci., Paris, Ser. IIa, vol.333, pp. 337-341, 2001. https://doi.org/10.1016/S1251 $-8050(01) 01647-0$

[11] Boutahar L., Maanan M., Bououarour O., Richir J., Pouzet P., Gobert S., Maanan M., Zourarah B., Benhoussa A., Bazairi H., "Biomonitoring environmental status in semi-enclosed coastal ecosystems using Zosteranoltei meadows," Ecological Indicators, vol.104, pp.776-793, 2019. https://doi.org/10.1016/j.ecolind.2019.04.039

[12] Benmhammed A., Laissaoui A., Mejjad N., Ziad N., Chakir E., Benkdad A., AitBouh H., ElYahyaouia A., "Recent pollution records in Sidi Moussa coastal lagoon (western 
Morocco) inferred from sediment radiometric dating," J.Environ.Radioact, vol.227， pp.106464， 2021. https://doi.org/10.1016/j.jenvrad.2020.106464

[13] Taylor S.R., McLennan S.M, "The Composition and Evolution of the Continental-Crust - Rare-Earth Element Evidence from Sedimentary-Rocks," Philosophical Transactions of the Royal Society of London, vol.301, no.1461, pp.381-399, 1981.https://doi.org/10.1098/rsta.19 81.0119

[14] Gromet L.P., Dymek R.F., Haskin L.A., Korotev R.L, "The North American shale composite: its compilation, major and trace element characteristics," Geochem. Cosmochim. Acta, vol.48, pp.2469-2482, 1984. https://doi.org/10.1016/ 0016-7037(84)90298-9

[15] Bounouira H., Choukri A., Cherkaoui R., Gaudry A., Delmas R., Mariet C., Hakam O. K., Chakiri S., "Multielement analytical procedure coupling INAA, ICP-MS and ICP-AES: Application to the determination of major and trace elements in sediment samples of the Bouregreg river (Morocco)," Journal of Radioanalytical and Nuclear Chemistry vol.278, no.1, pp.65-79, 2008. https://doi.org/10.1007/s10967-007-6937-9

[16] Taghia Y., Algouti A., Algouti A., Azzaoui K., Aydda A., "Envasement de la lagunesidimoussa. proceedings - 2nd International symposium of GIS Users," Meknès, Morocco pp.802-804, 2014.

[17] Menendez A., James R. H., Roberts S., Peel K., Connelly D., "Controls on the distribution of rare earth elements in deep-sea sediments in the North Atlantic Ocean," Ore Geology Reviews, vol.87 pp. 100-113, 2017. https://doi.org/10.1016/j.oregeorev.2016.09.036

[18] Kato Y., Fujinaga K., Nakamura K., Takaya Y., Kitamura K., Ohta J., Toda R., Nakashima T., Iwamori H., "Deep-sea mud in the Pacific Ocean as a potential resource for rare-earth elements," Nat. Geosci, vol.4, pp.535-539, 2011. https://doi.org/10.1038/ngeo1185

[19] Auger PA., Machu E., Gorgues T., Grima N., Waeles M., "Comparative study of potential transfer of natural and anthropogenic cadmium to plankton communities in the North-West African upwelling," Sci Total Environ, vol.505, pp.870-888, 2015. https://doi.org/10.1016/j.scitotenv.2014 .10 .045

[20] Gaudry A., Zeroual S., Gaie-Levrel F., Moskura M., Boujrhal F-Z., Cherkaoui El Moursli. R., Guessous A., Mouradi A., Givernaud T., Delmas R., "Heavy Metals
Pollution of the Atlantic Marine Environment by the Moroccan Phosphate Industry, as Observed through their Bioaccumulation in Ulva Lactuca," Water Air Soil Pollut, vol.178, pp.267-285, 2007. https://doi.org/10.1007/s11270 $-006-9196-9$

[21] Hannigan R., Dorval E., Jones C., "The rare earth element chemistry of estuarine surface sediments in the Chesapeake Bay," Chemical Geology, vol.272, pp. 20-30, 2010. https://doi.org/10.1016/j.chemgeo.2010.01.009

[22] Tostevin R., Shields G.A., Tarbuck G.M., He T., Clarkson M.O., Wood R.A., "Effective use of cerium anomalies as a redox proxy in carbonate-dominated marine settings," Chemical Geology, vol.438, pp. 146-162, 2016. https://doi.org/10.1016/j.chemgeo.2016.06.027

[23] Mejjad N., Laissaoui A., El-Hammoumi O., Benmansour M., Benbrahim S., Bounouira H., Benkdad A., Bouthir F.Z., Fekri A., Bounakhla M., "Sediment geochronology and geochemical behavior of major and rare earth elements in the Oualidia Lagoon in the western Morocco," Journal of Radioanalytical and Nuclear Chemistry, vol.309, no.3, pp.1133-1143, 2016.https://doi.org/10.1007/s10967-016-4 714-8

[24] Shields G., Stille P., "Diagenetic constrains on the use of cerium anomalies as palaeoseawater proxies: an isotopic and REE study of Cambrian phosphorites," Chem.Geol, vol.175, pp.29-48, 2001. https://doi.org/10.1016/S0009-25 41(00)00362-4

[25] Tranchida G., Oliveri E., Angelone M., Bellanca A., Censi P., D’Elia M., Neri R., Placenti F., Sprovieri M., Mazzola S., "Distribution of rare earth elements in marine sediments from the Strait of Sicily (western Mediterranean Sea): Evidence of phosphogypsum waste contamination," Mar. Pollut. Bull, vol.62, pp.182 - 91, 2011. https://doi.org/10.1016/j.marpolbul.2010.11.003

[26] Paul S.A.L., Haeckel M., Bau M., Bajracharya R., Koschinsky A., "Small-scale heterogeneity of trace metals including rare earth elements and yttrium in deep-sea sediments and porewaters of the Peru Basin, southeastern equatorial Pacific," Biogeosciences, vol.16, pp.4829-4849, 2019. https://doi.org/10.5194/bg-16-4829-2019

[27] Stamatis N., Kamidis N., Sylaios G., "Sediment and suspended matter lead contamination in the Gulf of Kavala, Greece," Environmental Monitoring and Assessment, vol.115, pp.433-449, 2006. https://doi.org/10.1007/s10661 $-006-7238-9$ 